\title{
Characteristic Biofuel Microalgae Chlorella sp. as Renewable Energy Source
}

\author{
Anggra Fiveriati, ${ }^{1, *}$ Yeddid Yonatan $^{2}$, Olga Anne $^{3}$, and \\ Praptiningsih Gamawati Adinurani ${ }^{4,5}$ \\ ${ }^{1}$ Mechanical Engineering, State Polythecnic of Banyuwangi, Jalan Raya Jember, Kabat, \\ Bayuwangi 68461, East Java , Indonesia \\ ${ }^{2}$ Ship Manufacture Engineering, State Polythecnic of Banyuwangi, Jalan Raya Jember, Kabat, \\ Bayuwangi 68461, East Java, Indonesia \\ ${ }^{3}$ Engineering Department of Marine Technology and Natural Sciences Faculty, Klaipeda University, \\ H. Manto g. 84, Klaipeda 92294, Lithuania, EU. \\ ${ }^{4}$ Indonesian Renewable Energy Society (METI), Menara MTH Lt, 10 Jalan. MT. Haryono Kav. 23, \\ Center Jakarta 12820, Indonesia \\ ${ }^{5}$ Department of Agrotechnology, Merdeka University of Madiun, Jl. Serayu No.79, \\ Madiun 63133, East Java, Indonesia
}

\begin{abstract}
World consumption of energy is estimated to increase by $49 \%$ from 2007 to 2035, which means averagely $1.4 \% \mathrm{yr}^{-1}$. Many countries in the world began to develop alternative energy that can overcome the resources. Microalgae is one of the renewable energy that has excellent potential for making biodiesel because it contains much oil. Microalgae is the fastest organism in the photosynthesis, so it makes microalgae have high productivity. In this article, researchers use Chlorella sp. because these microalgae contain oil up to $28 \%$ to $32 \%$ from its dry weight, and on the other hand, this type of microalgae is easy to grow and easy to harvest. From the experimental results, the density characteristics of biodiesel Chlorella sp. have values from $0.84 \mathrm{~g} \mathrm{~mL}^{-1}$ to $0.848 \mathrm{~g} \mathrm{~mL}^{-1}$, and it is lower than the density of petroleum (diesel), and viscosity value from $2.5 \mathrm{cSt}$ to $3.91 \mathrm{cSt}$, cetane numbers 51.17 to 53.72 also heating value $44.04 \mathrm{~mJ} \mathrm{~kg}^{-1}$ and Flashpoint $131{ }^{\circ} \mathrm{C}$. The characteristic result shows that the Chlorella sp. microalgae biodiesel is still in SNI standard (Indonesia National Standard) so that the Chlorella sp. can be used as a substitute diesel fuel.
\end{abstract}

Keywords: $3^{\text {rd }}$ generation biodiesel, alternative energy, clean energy, substitute diesel fuel

\section{Introduction}

The development of biofuel as renewable energy becomes really important because many countries make biofuel as the key point to reduce the oil crisis in the developed country. Biodiesel has a high potential to replace the petroleum product because many researchers have concluded that biodiesel fuel can be used without changing the design of the existing diesel engine. Biodiesel has many advantages which are: contain low sulfur, contain low

\footnotetext{
*Corresponding author: anggrafiveriati@poliwangi.ac.id
} 
aromatic essence, high etan number, and biodegradable. On the other hand, biodiesel is better than fossil oil because the usage of biodiesel has lower $\mathrm{CO}_{2}$ emission [1].

Biodiesel is usually produced from oleaginous crops, such as rapeseed (Brassica napus Linn.), soybean (Glycine max (L.) Merr.), sunflower (Helianthus annuus L.) and palm oil (Elaeis guineensis Jacq.). However, the use of microalgae can be a suitable alternative feedstock for next-generation biofuels [2]. The biodiesel from plant oils such as corn (Zea mays L.), soybeans (G. max), purging nut (Jatropha curcas L.) and palm oil (E guineensis) have disadvantages, like time of harvesting of plants which is 3 mo to $5 \mathrm{yr}$ apart, to make the plants productive again to produce the oil. On the other hand, the oil substitution from corn oil, soybean, and palm oil will clash with the interests of human food consumption, and if the oil from plants is still produced to substitute petroleum (diesel), the price will not competitive [3-5].

The process of making biodiesel from animal fat is not yet in optimum condition. Animal fats contain free fatty acids, and high-water content which can reduce the quality of biodiesel [6], besides animal fat is still needed for human consumption and the manufacture of oleochemical products. For animal fat waste, such as chicken fat, it is generally used for animal food and fish. To overcome this problem, it is necessary to look at other natural materials that have the potential of making biodiesel, and one of the natural resources that have the potential to become biodiesel is microalgae.

Anne, Bugajev, and Koreiviene [7] has conducted a survey in the Curonian Lagoon in Lithuanian as a step to implement microalgae cultivation. Reference [8] has described large-scale microalgae cultivation, while [9-11] suggested increasing efficiency with the integration of algae cultivation as a biogas purification

Table 1. Comparison of microalgae with other biodiesel feedstock [6]

\begin{tabular}{|c|c|c|c|c|}
\hline Oil feedstocks & $\begin{array}{c}\text { Oil content } \\
\text { (\% dry weight } \\
\text { Biomass })\end{array}$ & $\begin{array}{c}\text { Oil yield } \\
\left(\text { L oil ha-1 } \mathbf{y r}^{-1}\right)\end{array}$ & $\begin{array}{c}\text { Land use } \\
\left(\mathrm{m}^{2} \mathrm{yr}^{-1} \mathrm{~L}^{-1}\right. \\
\text { biodiesel) }\end{array}$ & $\begin{array}{c}\text { Biodiesel } \\
\text { productivity } \\
(\mathrm{L} \text { biodiesel } \\
\left.\mathrm{ha}^{-1} \mathrm{yr}^{-1}\right)\end{array}$ \\
\hline \multicolumn{5}{|l|}{ Oil Seeds } \\
\hline $\begin{array}{c}\text { Microalgae } \\
\text { (low oil content) }\end{array}$ & 30 & 58700 & 0.2 & 61091 \\
\hline $\begin{array}{c}\text { Microalgae } \\
\text { (medium oil content) }\end{array}$ & 50 & 97800 & 0.1 & 101782 \\
\hline $\begin{array}{c}\text { Microalgae } \\
\text { (high oil content) }\end{array}$ & 70 & 136900 & 0.1 & 142475 \\
\hline Corn (Z. mays) & 44 & 172 & 56 & 179 \\
\hline Soybean (G. max) & 18 & 636 & 15 & 661 \\
\hline $\begin{array}{l}\text { Sunflower } \\
\text { (H. annuus) }\end{array}$ & 40 & 1070 & 9 & 1113 \\
\hline $\begin{array}{c}\text { Palm oil } \\
\text { (E. guineensis) }\end{array}$ & 36 & 5366 & 2 & 5585 \\
\hline
\end{tabular}

Indonesia, as a tropical country and only has two seasons, make plants can photosynthesis, including microalgae, which can flourish because microalgae get enough sunlight, which is $12 \mathrm{~h} \mathrm{~d}^{-1}$. In other facts, that $67 \%$ of Indonesia territory is the sea, this opportunity makes microalgae can grow if cultivated in the area around the coast. Unlike 
other plants, microalgae growth is fast and rich of the oleaginous organic compounds. Harvesting of microalgae can be done continuously (every day) [12].

Microalgae cultivation is 10 to 20 times more productive in 1 ha of land than other plants. Table 1, so it is very potential in biofuel production without sharing food production with biofuel production. Triglycerides that contained in microalgae are easily extracted and transesterified to get biodiesel [13]. From the several types of microalgae, the research shows that one type of microalgae that can produce lipid products is Chlorella sp. Compared to other types of microalgae, the oil content in this microalgae is quite high at $28 \%$ to $32 \%$ of its dry weight [12].

\section{Method}

\subsection{Cultivation of Chlorella sp.}

Cultivation of Chlorella sp. starts from isolation and then developed gradually in stages, in the beginning, Chlorella sp. only has a few millimeters and then gradually increased to a larger volume, then reach a mass scale. Mass production of Chlorella sp. uses chemicals or special equipment to obtain a pure culture. Steps to carry out cultural activities begin with preparation, sterilization, fertilizer application, density calculation, and harvesting.

The cultivation step of Chlorella sp. starts from preparing a culture medium where the media used in this culture is a pond. The initial step is to wash the culture pond; washing culture ponds is done by watering the culture ponds with fresh water. The purpose of watering the pond is that the rest of the previous culture does not become dry, because if it is dry, then the rest of the previous culture is challenging to clean.

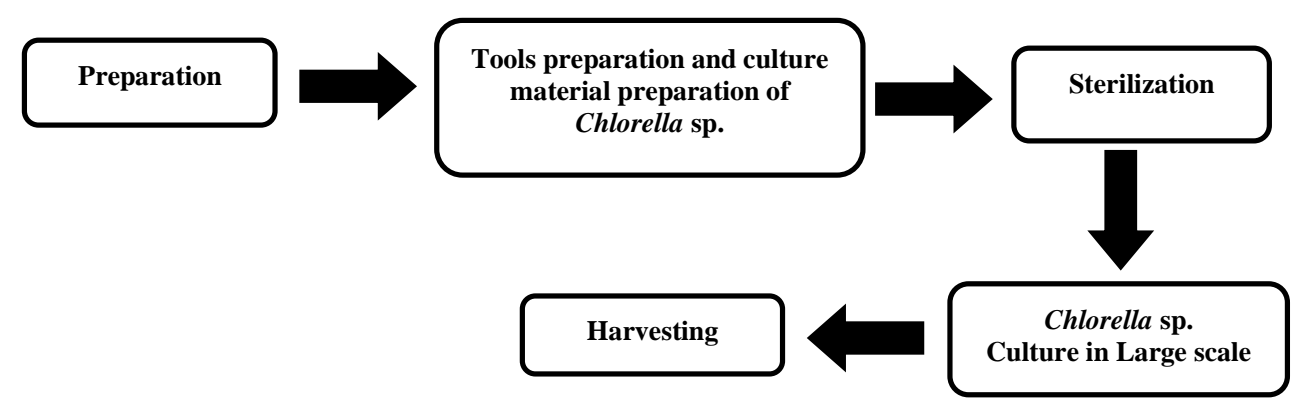

Fig. 1. Cultivation step of microalgae Chlorella sp.

The next stage is the preparation of tools and culture materials; the used tools are: aerator pipe, dipper, wood and bucket, and the material for microalgae cultures are Chlorella sp. seeds, chlorine and Na-Tiosulfate in Figure 1. Chlorine is used for sterilization of tubs, and Na-Thiosulfate is used to neutralize chlorine. Stages of pond sterilization are doused with fresh water, then the aeration pipe, and the cover pipes are brushed until it is clean to avoid contamination after cleaning the ponds filled with seawater. The next step is, give the chlorine to the pond at a dose of $15 \mathrm{mg} \mathrm{L}^{-1}$ to $20 \mathrm{mg} \mathrm{L}^{-1}$ for $24 \mathrm{~h}$. Basically, preparation for the culture of various types of phytoplankton is the same, which is the sterilization of tools and materials aimed at killing unwanted microorganisms [14]. 


\subsection{Biodiesel from microalgae Chlorella sp.}

The method used in the process of making biodiesel using Chlorella sp. is microwaveassisted transesterification in situ. The microwave used to speed up the reaction time by using a homogeneous catalyst that is acidic. Microwaves are electromagnetic waves with super high frequency (Super High Frequency, SHF), which is between $300 \mathrm{Mhz}$ to 300 Ghz. Microwave has a wavelength range from $1 \mathrm{~mm}$ to $1 \mathrm{~m}$.

The use of microwaves has been widely applied in various fields of science. In electronics such as radio, television. In communication technologies such as radar, satellite, distance measurement, and for the study of material properties. The heat capacity of microwave radiation is proportional to the dielectric property of the material and the distribution of its electromagnetic charge [15].

The heating method can cause the lipid extraction process to take place quickly and simultaneously convert it into FAEE (Fatty Acid Ethyl Ester) or FAME (Fatty Acid Methyl Ester) . For the microwave effect: (i) the thermal effect caused by microwaves will increase the alcohol properties to extract oil from algae biomass in suspension (diffusion extraction) and then, (ii) the extensive microwave effect causes the penetration of solvents through the cell wall and then the methanol is evaporated, causing the cell to break open to release oil $[16,17]$. The tested characteristics of biodiesel include density, viscosity, and flash point values to determine the quality of biodiesel.

\section{Result and discussion}

The first step experiment is the application of fertilizer before Chlorella sp. added to the culture pond. The experiment was conducted for $11 \mathrm{~d}$ from the culture stage of Chlorella sp., the harvesting stage until the stationary stage as explain in Figure 2.

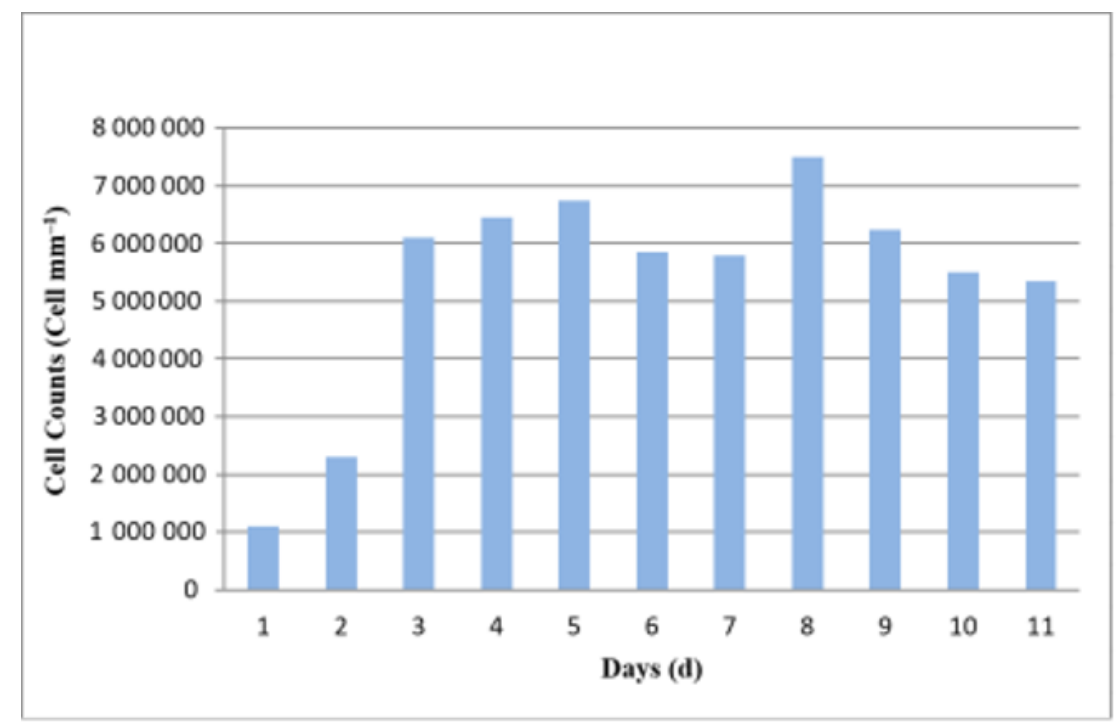

Fig 2. The density of Chlorella $\mathrm{sp}$. (Cell $\left.\mathrm{mm}^{-1}\right)$

Figure 2 shows the growth of Chlorella sp. from the 1 st $\mathrm{d}$ to the 11 th $\mathrm{d}$. The growth rate of Chlorella sp. is increasing on 1 st $\mathrm{d}$ to 8 th $\mathrm{d}$. On the 8th $\mathrm{d}$, Chlorella sp. increases the peak density. However, on 9 th $\mathrm{d}$ to 11 th $\mathrm{d}$ are decreasing. 
Figure 2 also shows that the growth of Chlorella sp. cultured on the 1 st $\mathrm{d}$ has a resting phase or adaptation phase. In this phase, the cell size increases physiologically. The $2 \mathrm{nd} d$ to the 5 th $\mathrm{d}$ is an exponential phase, which is proliferating to the optimal culture conditions that are showing us the maximum growth rate. On the 6th $\mathrm{d}$ and 7 th $\mathrm{d}$, Chlorella sp. production was affected by microclimate because, at that time, it is rained, so the temperature in the pond is decreased.

The highest density occurs on the $8^{\text {th }}$ day because on the $8^{\text {th }} d$ is the peak of the exponential phase (harvesting time). Table 2 showed, on $9^{\text {th }}$ to $11^{\text {th }} \mathrm{d}$ called the stationary phase of microalgae production because, in this phase, the production rate is the same as the death rate of microalgae. Biodiesel production from microalgae provides technical and economic feasibility that also has the potential for $\mathrm{CO}_{2}$ sequestration and is, therefore, likely to find wide acceptance. Algal biofuels appear to be the only current renewable source that could meet the global demand for transport fuels. Microalgal biofuels are also likely to have much lower impacts on the environment and the world's food supply than conventional biofuel-producing crops [18].

Table 2. Comparison of Microalgae properties

\begin{tabular}{cccc}
\hline Characteristic & Biodiesel Chlorella sp. & SNI standart $\left.{ }^{*}\right)$ & Diesel \\
\hline Density $\left(\mathrm{g} \mathrm{m}^{-1}\right) 40{ }^{\circ} \mathrm{C}$ & 0.84 to 0.848 & 0.840 to 0.890 & 0.82 to 0.87 \\
Viscosity $40{ }^{\circ} \mathrm{C}(\mathrm{cSt})$ & 2.50 to 3.91 & 2.3 to 6.0 & 1.6 to 5.8 \\
Setana Number & 51.17 to 53.72 & Min 51 & Min 45 \\
Heating Value $\left(\mathrm{MJ} \mathrm{kg}^{-1}\right)$ & 44.04 & 37.11 & 43.26 \\
Flash Point $\left({ }^{\circ} \mathrm{C}\right)$ & 131 & Min 100 & Max 100 \\
\hline
\end{tabular}

Note: *)Indonesia National Standard

From the experimental results, the density characteristics of biodiesel Chlorella sp. have values from $0.84 \mathrm{~g} \mathrm{~mL}^{-1}$ to $0.848 \mathrm{~g} \mathrm{~mL}^{-1}$. It is lower than the density of petroleum (diesel), and viscosity value from $2.5 \mathrm{cSt}$ to $3.91 \mathrm{cSt}$, cetane numbers 51.17 to 53.72 also heating value $44.04 \mathrm{~mJ} \mathrm{~kg}^{-1}$ and Flashpoint $131{ }^{\circ} \mathrm{C}$. This characteristic result shows that the Chlorella sp. microalgae biodiesel is still in SNI standard so that the Chlorella sp. can be used as a substitute diesel fuel.

\section{Conclusion}

Microalgae Chlorella sp. have the potential to be essential and sustainable renewable energy feedstock that could meet the global demand. Microalgae Chlorella sp. is a promising raw material in the future as biodiesel; the advantage of microalgae is quite extensive in Indonesia. Since Indonesia is a maritime country, besides that, microalgae can produce more oil content compared to other biodiesel raw materials, and microalgae do not interfere with the human food chain. The growth process of microalgae Chlorella sp. is very fast and can be harvested in $8 \mathrm{~d}$. The process of clusterization is very easy, makes microalgae more suitable as biodiesel raw material. The comparison result of microalgae properties with petroleum showed that the microalgae are still in SNI standard, but the heating value and flash point value is still high. According to the data, it can be concluded that the microalgae Chlorella sp. can be used as biodiesel fuel. 


\section{References}

1. J.V. Gerpen, Fuel Processing Technology, 86,10:1097-1107(2005).

https://www.sciencedirect.com/science/article/pii/S0378382004001924

2. L. Gouveia, A.C. Oliveira, Journal of Industrial Microbiology and Biotechnology, 36,2:269-274(2009). http://doi:10.1007/s10295-008-0495-6

3. Á.C. López, D.Y. Rade-Loor, M. Siegmund-Schultze, M. Iriarte-Vera, J.M. Domínguez-Andrade, J. Vargas-Hernández, et al., Forests, 9, 10:611(2018). doi:10.3390/f9100611 https://www.mdpi.com/1999-4907/9/10/611

4. P.G. Adinurani, T. Liwang, Salafudin, L.O. Nelwan, Y. Sakri, S.K. Wahono, et al., Energy Procedia 32:84-89(2013). doi: 10.1016/j.egypro.2013.05.011 https://www.sciencedirect.com/science/article/pii/S1876610213000131

5. P.G. Adinurani, R.H. Setyobudi, S.K. Wahono, A. Sasmitod, L.O. Nelwan, A. Nindita, et al., International Journal of Renewable Energy Development, 3,1: 73-78(2014). https://doi.org/10.14710/ijred.3.1.73-78. https://ejournal.undip.ac.id/index.php/ijred/article/view/6149

6. O. Anne, D. Bugajev, J. Koreiviene, Int. J. Environ. Res., 9,1:233-246(2014). https://www.researchgate.net/publication/271143928_Determining_Optimal_Growth_ Conditions_for_the_Highest_Biomass_Microalgae_Species_in_Lithuanian_Part_of_t he_Curonian_Lagoon_for_further_Cultivation

7. J. Seppälä, K. Spilling, K. Manninen, E. Salo, B. Cahill, F. Gröndahl, et al. Largescale microalgae cultivation, Chapter: 6. In: Compendium: An assessment of innovative and sustainable uses of Baltic marine resources. A. Schultz-Zehden, M. Matczak (Eds.), Berlin: Maritime Institute in Gdańsk, (2012). pp 125-145. https://www.researchgate.net/publication/282669922

8. S. Rajvanshi, M.P. Sharma, Journal of Sustainable Bioenergy Systems, 2,3:4959(2012). http://dx.doi.org/10.4236/jsbs.2012.23008

9. Ichsan, H. Hadiyanto, R.H. Setyobudi, Energy Procedia, 47:143 - 148(2014). doi: 10.1016/j.egypro.2014.01.207 https://core.ac.uk/reader/82608242

10. P.G. Adinurani, R.H. Setyobudi, S.K. Wahono, M. Mel, A. Nindita, E. Purbajanti, et al., Jurnal Teknologi (Sciences \& Engineering), 78,4-2:175-178(2016).

http://www.jurnalteknologi.utm.my/index.php/jurnalteknologi/article/view/8201/4942

11. Salafudin, R.H. Setyobudi, S.K. Wahono, A. Nindita, P.G. Adinurani, Y.A. Nugroho, et al., Procedia Chemistry, 14:387-393(2015).

https://doi.org/10.1016/j.proche.2015.03.069

12. Y. Chisti, Biotechnology Advances, 25,3:294-306(2007). https://doi.org/10.1016/j.biotechadv.2007.02.001

13. K.K. Sharma, H. Schuhman, P.M. Schenk, Energies, 5,5:1532-1553(2012). https://www.mdpi.com/1996-1073/5/5/1532

14. A.R. Andersen, Algal Culturing Techniques, USA: Elsevier Academic Press eBooks (2005).

https://www.researchgate.net/file.PostFileLoader.html?id=5501aad8d685cce5228b456 7\&assetKey=AS\%3A273731753054213\%401442274143544\#page=76

15. T. Santos, M.A. Valente, J. Monteiro, J. Sousa, L.C. Costa, The Journal of Applied Thermal Engineering, 31,16:325-326(2011).

https://www.sciencedirect.com/science/article/pii/S1359431111003127

16. J. Liu, Z. Sun, H. Gerken, Recent Advances in Microalgal Biotechnology, USA: OMICS Group eBooks (2016) https://pdfs.semanticscholar.org/f96c/fc29ad6b97369c3bb85200fa244ffe71d348.pdf

17. V. Feddern, A.C. Junior, M.C. De Prá, P.G. de Abreu, J.I.S. Filho, M.M. Higarashi et al., Animal Fat Wastes for Biodiesel Production, Biodiesel - Feedstocks and Processing Technologies, Margarita Stoytcheva and Gisela Montero, IntechOpen, 
[Online] Available from: https://www.intechopen.com/books/biodiesel-feedstocksand-processing-technologies/animal-fat-wastes-for-biodiesel-production (2011).

18. P.M. Schenk, S.R.T. Hall, E. Stephens, U.C. Marx, J.H Mussgnug, C. Posten, et al., Second Generation Biofuels: High-Efficiency Microalgae for Biodiesel Production, Bioenergy Research, 1,1:20-43(2008). http://doi:10.1007/s12155-008-9008-8 